\title{
THE CIREBONAN THEATRICAL PERFORMING ART IN THE MIDDLE OF GLOBALIZATION EXPOSURE
}

\author{
Dadang Supardan, Didin Saripudin, Ayi Budi Santoso, and Syarif \\ Muis $^{1}$
}

\begin{abstract}
This study is based on the concern to the tendency of a strong negligence towards the basic values of the Cirebonan theatrical perfroming arts due to the globalization exposure that affect to the contra development or marginality of traditional arts. The problem formulation developed in the research includes: (1) What is the origin of the Cirebonan play performing art in the coastal areas of West Java border? (2) What are the purposes of the art to be performed in Cirebon a region located in the coastal areas of West Java? (3) What steps in this theatrical performing arts in order to be performed and enjoyed as ordinary folk art performances? (4) What is the philosophical value of is art so that it can be contributed to the history education? (5) What is effort to be done in order improve the historical awareness of local people in enjoying this performing arts regaridless to the threat of marginality caused by the globalization exposure? The method used in this research is a qualitative approach combined with historical and ethnographic methods. The research results are as follows: (1) The origins of Cirebonan theatrical play performing arts around 1943 or 1944 that was during the Japanese occupation in Indonesia. The origin name was Reog Sepat, then became Tonil Cahya Widodo, later on it turned into a combination of Reog Sepat and Tonil Cahya Widodo. (2) The objectives of Cirebonan theatrical play performing arts include; entertainment, telling the chronicles of a certain area development, providing exemplary behavior of a hero, as well as for the preaching media, and socialization of the government programs. (3) The stages of the learning implementation include the opening music (tatalu), gimmick scene (surpraised with stage tricks, such as fireworks) opening dance; the theatrical play performances; closing, with music and the theater leader epilogue. (4) The philosophical values use for history education is a blend of cultural and spiritual that have characteristics, include (a) director of interference who is not dominant: the players are free to improvise as along they still stick in from the core story. (b) the diversity of players' everyday profession, such as rickshaw drivers, domestic workers, fishermen, and farmers, (c) the canvas painter's involvement in the setting screen display on the stage for a story in accordance with the episode. (5) The efforts to preserve the Cirebonan theatrical performing art; both artists and the government have tried to preserve it, is not optimal, because lesser Cirebonan theatrical group got a call to perform, as well as there is no efforts to include it as the local content in the schools curriculum
\end{abstract}

Key words: history, learning, Cirebonan theaterical, globalization

\footnotetext{
${ }^{1}$ Dadang Supardan, Didin Saripudin, Ayi Budi Santosa, and Syarief Moeis, lecturer of History Education Department in Indonesia University of Education (UPI). For academic interest, the author can be contacted through the office address: Dr Setiabudhi Street, No. 229, Bandung, and email address: dangsu57@yahoo.com.
} 


\section{Introduction}

Every society has a tradition essentially rooted in the belief of the virtue of his ancestors, so does the society in the northern coastal of the West Java and Central Java border, particularly in the area of Cirebon-Indramayu they have a "theatrical"performing arts. This Cirebon theatrical performing art is unique and beautifull, known by the people of West Java as "Sandiwara Cirebonan" or "Masres" (the name of a kind of thread used for fishing nets) in the 1940s, which appeared when Cirebon was occupied by the Japanese colonialists (Sumardjo, 2004:243). The musical instruments used in theatrical Cirebonan are gamelan pelog with waditra such as bonangs, kemyang, saron, titil, penerus, large and small gongs, drums, ketipung dogdog, tutukan, kenong (jenglong), kecrek, flute, and gambang. In the recent development, the modern musical instruments are added, such as keyboards and electric guitars. While another equipment that supports Cirebonan theatrical performing arts include properties, the display, and the decoration (Mustafa, 2002: 132 ).

In the current Cirebonan theatrical performances, many taken from the featured stories of Babad Cirebon, like the play of Nyi Mas Gandasari, Prince Walangsungsang, Ki Gede Trusmi, Tandange Ki Bagus Rangin, Pusaka Golok Cabang, and others. However, sometimes it featured the fairy tales or legends of Java society in general, especially on the show during the day. But during the night show, the stories performed are mostly from Babad Cirebon and finish early in the morning. Because of its egalitarian, many Cirebon theaterical performing arts also include dangdut music, or sometimes tayuban as an interlude in the theaterical performances. Cirebonan theatrical performance in the evening usually starts at 20:00 and finishes at 03.30 in the morning. The Cirebonan theatrical performing art's structure is as follows: the opening music (tatalu); scene gimmick (surpraise with stage tricks, such as fireworks); opening dance; the theatrical performances; closing, with music and the theater leader's epilogue (Haryani , 2013 : 15 ; Marianti , 2007: 25 ).

This theatrical art was very popular in the 1970s. Thus during that time many Cirebonan theaterical performing arts groups were emerging in every village and sub-district. This Cirebonan theatrical art still exists in the surrounding community. This existance is inseparable from the support of the people involved in this art that still require the performing arts as an accompanist in ceremonies such as initiation, cathartic, and magical sympathetic or wedding, circumcision, etc. (Sumardjo, 2004: 244).

Until the late 1970s this art was often played by children in rural Cirebon, even Indramayu, Majalengka, Kuningan, and western district of Brebes. This Cirebonan performing art was so populat that many children played it in as their game on the yard, field, or house yard. But ironically since the mid-1980s, the game was already hard to find. This is because lesser opportunity to perform traditional arts itself. Back in the villages they usually performed at a celebration party, either circumcision or wedding parties. But now, a celebration party was already switched to other forms of entertainment, such as video, layar tancap, a single organ, 
dangdutan, and others. The lesser interest for this performing arts is reasonble because of some reasons. First, the theaterical performing art is impractical because there are many actors and the musician or the nayaga (the gamelan players) that should be served by the host, at least involving about 50 people for one theatrical group. The personels consist of 15 gamelan players, 10 equipment personels, and the actors (Mustafa, 2002: 207). Second, the people's tastes, especially the youth, has shifted to the more popular entertainments which is instant and practical, such as the single organ, dangdutan, and so on .

The lesser chance to perform degrades the quality of the local arts, therefore the actors felt abandoned by their supporters. Moreover, the local youth has no interest to pursue the traditional arts, because it is considered to have no prospects. Many former Cirebon performers's life are not good, some of them even do odd jobs. They easily "plead" that the decline of the Cirebonan theatrical performaning art is solely because of the strong exposure to modernization and globalization. They hardly examined the internal factors behind it. As an example, the aspect of "acting" or "theater world" was never analyzed as a flaw or weakness that hit the player in the act.

The world of actors or theater in Indonesia, Tommy F. Awuy in his writing titled Teater Indonesia dalam Ambiguitas dan Ironi, stated that the Indonesian theater is a theater that is full of ambiguity (Awuy, 1999:333). This is caused by many things, one of them is because Indonesia theater is still amateur theater, both in terms of directing, acting, and artistic arrangement. Each of these three aspects has no exact particular function and duties. Furthermore, Awuy explain that this ambigiuty also due to the fanatics who say that the art of theater, drama, plays as if it depends on the expression of reality, not a performance with a high ilusivity. In fact theater should be evasive, refusing, and even transcend reality. But on the other hand the art itself faces the changes in society and socio-cultural environment as the result of globalization laden with technology progress.

Giddens (1990:64) said that currently the process of globalization is increasingly perceived as a part of our lives, where the "intensification of global social interaction is increasingly happening". The indicator is the establishment of the information superhighway; the highway of information with a very large capacity that enable traffic information super in high speed, political boundaries between nations of the world is diappearing (Ohmae, 2002:171-173 ; 1991:183-186). Boyer and Drache (1996:64) in the States Against Market: Limits of Globalization explain the globalization has subjective and objective reality. The subjective reality indicates a process in human consciousness that look and feel themselves as participants of increasingly unified global community. While the objective reality of globalization is a process of space and time narrowing, "shrinking" world that thrive in conditions of paradoxes. The paradox between the universalization versus pluralization, between integration versus fragmentation, between centralization versus autonomy, between competition versus cooperation, and so on (Naisbitt, 1994: 1-51). Globalization is causing a popular concern, and so much interest and public anxiety 
regarding globalization (Ritzer and Goodman, 2004:587). The uniqueness of globalization is not simply linked to that process is "going on" but also "how is our preparation to face globalization". Because we realize that the insistence of globalization is not likely to be encountered confrontationally, but it should not damage the the lives aspects, rights, and obligations of every nation.

Kennedy (1995:290-292) has warned us in the description which is worrying for us, that there will be the group of countries that emerge as the winner and the other disadvantaged group as the loser, when the fundamental and revolutionary changing process happens. The existence of the winner and losers group is due to the lack of unanimity of perception and response of each country and nation toward the revolusiener globalization. There are a few countries that were able to quickly adjust to changes (fast adjusters) that are also have such a bold reforms, such as in several countries in East Asia. While the others appear as a slow adjuster because they are not ready to face such changes. Obviously we do not want to be the loser group. But the issue is not the matter of want it or loses it, but ready or not. This is where a global perspective in the history of education in relation to the pressing of globalization is required. Therefore, Diaz (1999:37-38) explain that it is an impossible thing and will only create new problems if we are to react in confrontational ways especially without any real preparations through human resource development.

Mickletwait and Wooldridge (2000:29) in the Future Perfect: The Challenge and Hidden Promise of Globalization explain that there are three engines gloaliztion to look at globalization from a different aspect. They review the motors that drive the globalization which result in a fast process of globalization through the boundaries between nations/states. Furthermore, they mentioned that globalization is driven by three particular engines, that include technology, capital markets and management.

We realize the powerful resonance that hit in the globalization process, especially for developing countries, thuswereallyneed to respond it carefully and wisely, which requires real preparation steps through education and skills that strengthen the national identity. Only by strengthening the education and development of a strong national culture and implement the principle of interdependence in a global society, the resilience of a culture can be maintained and improved to live harmonioualy in uniformity and diversity.

\section{Problems Identification and Formulation}

The problems that arise in analyzing traditional the Cirebonan theatrical prforming art revolves around the background of the performance, especially for people in the border areas of West Java coast, Cirebon. From the background of this art performance can be traced the purposes of performing this traditional theatrical art, which is usually as the entertainment in the spare time, that is attractive and interesting. While other issues that also important to be studied is how the stages in performing the Cirebon theaterical performing art to be an attractivetraditional performing arts to the local community. The philosophical values is also important, which contribute to the history learning. 
Because the the performers of Cirebonan theaterical prforming art that portray their character provide lesson in appreciating the role and the character played. But on the other hand, this highly philosophical art and a valuable asset of the nation is also on the decline, especially after it was struck by globalization, where youth and Cirebon people are less interested in the art and more interested in organ tunggal, dangdutan, and another modern arts. Cirebon people themselves have little sense of history to keep and develop the traditional art in the effort of preserving the national art identity as local genius or cultural identity to be proud of, despite the law to preserve heritage values that have existed since the New Order (Orde Baru) government.

The following are the detailed formulation of the problem:

a. How is the origin of the Cirebonan theaterical performing art in coastal areas of West Java border?

b. For what purposes theatrical performaning art is performed in Cirebon or the coastal areas of West Java's border?

c. How is the performance stage of the theatrical performing arts so it can be enjoyed as art performance of the locals?

d. What is the philosophy value of this Cirebonan theaterical performing art that can be contribute in the history education?

e. How is the effort to increase the history awareness of the local community to enjoy the performing arts plays that is increasingly marginalized by the globalization exposure?

\section{Reasearch Purpose and Benefits}

Based on the formulation of the problem stated above, the purpose of the research are:

a. Analytically describe the origins of the theatrical performaning art in the area of Cirebon, which is now is increasingly marginalized by the global popular culture.

b. Explaining the objectives of the performing arts, since it was staged in the past to and its present dynamics.

c. Analytically explain the stages of the performing arts from the beginning of the show to the end, as well as its dynamics, compare to past and present arts.

d. Describein analytical philosophyvalues that can be taken from the Cirebonan theaterical performing arts for history lesson in school.

e. Explaining the concrete efforts of both the theatrical arts performers, community, and local government in preserving and developing the performing arts .

\section{Research Urgency}

a. The absence of historical - ethnographic studies that analyze in depth about the Cirebonan theatrical performing art as the nation's artistic and cultural asset valuable in of the nation's character development.

b. The Importance of social values and cultural arts assessment that developed in the northern coast of West Java eastern border area that can be transmitted, revitalized, and transformed to the younger generation and society, as an apparent attempt to 
support the resilience of the nation's culture which is facing a crisis of art and culture.

c. Strengthen and preserve local culture by exploring and developing the basic values of "national identity" (the local genius), which is the manifestation of historical awareness development as an intellectual orientation that is creative, introspective, and continue introspection. In this case includes the effort to put yourself and the existence of life in its sosio-cultural configuration, which will emerge the position awareness in the presence of life itself in a whole.

\section{Literature Study}

\section{Theaterical Performing Art}

The word "sandiwara" (theaterical)" was put forward for the first time by PKG Mangkunagara VII. According to him, this word was as a replacement of the word 'toneel' (In Dutch, meaning "drama" or "show"), which received attention among the educated people, eventhough Dutch was commonly used among them in that era. The new word "sandiwara" is formed from the word "sandi" (Java) means secret and "Wara" means lesson (Haryani, 2013:15). According to Ki Hajar Dewantara, sandiwara (teaterical performing art) is teaching performed with the symbolic. Such as in a brief explanation that the word sandiwara is to replace the the word toneel (Dutch). The actual meaning of the word sandiwara has more right sense than the word toneel (Dutch language), which mereley means show. Similarly, if it is also compared to word drama in the Greek, which original meaning is "action", then simply refered to the act on the stage. Unfortunately, that sense of the word is now declining, even for some people the words refer to a feeling of "abject" or teasing.

"Sandiwara" is a stage performance of a story or also called lakkon in the Javanese. A theaterical performing art can be performed based on scenario or not. If it is perfomed not base on scenarion, then everything is staged spontaneously with a lot of improvisation. In general, the term "sandiwara" in Indonesian is synonymous with drama. However, the term is specifically refers to the Indonesian traditional theatrical arts plays, especially in the area of West Java (Marianti, 2007:25). The Sundanese or Cirebon theatrical groups can be found in West Java (especially around Cirebon and Indramayu), and Jakarta, one of the famous theatrical group is the group of Sandiwara Sunda Miss Tjitjih which based in Cempaka Baru Timur, Central Jakarta. The play story of this theaterical group can be romance, comedy, horror, tragedy, or historical romance (Encyclopedia Indonesia: 1135).

The Cirebonan theatrical performaning art popular in West Java is called Masres, that basically a theatrical art that known by the people of West Java in the 1940s, when Cirebon was occupied by the Japanese colonialists (Sumardjo, 2004: 243). Based on the information gathered by the Cirebon theatrical figures today, it is mentioned that during the Japanese occupation in Indonesia, in the area of Cirebon emerging arts community that isfavored by Cirebonan Reog, which is known as Reog Sepat. The Reog performance consisted of two parts. The first part was bodoran/comedy, and a second part was drama that takes account 
of the habits of the local community. At the same time, in Jamblang Klangenan there were also a toneel group with the name of Cahaya Widodo. This gorup every day for months did "narayuda" or "ngamen", street performing (Sumardjo, 2004: 244).

Furthermore, Sumardjo said that both types of arts had inspired a young man from the village of Langgen, Wangunarja Village, Klangenan, Cirebon, named Mursid to establish a new art in Cirebon. Mursid gather the youth from the community to jointly establish associations that blends Reog Sepat and Tonil (Toneel) Cahya Widodo. The art style is a theaterical performing art in Cirebonan style with music by waditra in the rythim of Prawa. The fusion art called jeblosan that, according to them, means tonil show without screen cap (jeblas-jeblos; Cirebon language). Some were calling it Bungkrek (Cirebon language which means the single person [the youth] that are often do angkrak-engkrek [dancing]).

Because Jeblosan was heavily influenced Ketoprak/tonil/Cahya Widodo opera, it is not surprising that story origin delivered at that time was from Central Java and East Java. But sometimes the story is taken from the West Java folklore, a region origin, or folk tales. In a way, jeblosan was very popular in the community. At that time the entire actor were maleand were also the independence fighters. This was also a medium to spread awareness to fight against the colonialist through the act plays.

In 1946 in the village of Kebarepan, Plumbon District, Cirebon there were similar art named Langendriyo, initiated by Suwandi and Mursid, from Barepan village. Langendriyo and Jeblosan were almost the same as Cahya Widodo tonil, although there are differences in the language of delivery. In Langendriyo, the story was presented in the Java language, while the language used jeblosan was a mix of Cirebon Javanese language and the Java language (Marianti, 2007: 15).

In 1949, langen jeblos instruments were improved, by using the stage. The name of jeblos was changed into langen perbeta which means lasykar/army (code language), the Former Army Union. And in the fifties it was renamed again to the Sari Sasmita which serves as an information medium.SariSasmita popularitywas began. From night to night, in any celebration season, the performance art had no break in accepting invitation of the fans. In 1952 in the village of Bojong Wetan, Klangenan District, also had similar performing art under the name of Sanpro (Sandiwara Proletar). Its founder was H. Abdullah, who was the head of the local village. Then, in 1956, in Bedulan, Suranenggala Village, North Cirebon, there was also a performing arts under the name of Masres (the name of a type of yarn used for making fishing nets). One of the founders, Mrs. H. Sami, known as the Cirebonan singer. And, in 1956, political parties began to look at the theatrical arts as the campaigns media for their interests. In Wetan Bojong village, Klangenan District, Cirebon the Partai Sosialisme Indonesia/Indonesian Socialism Party (PSI) leaders established a performing art association to replace Sanpro, under the name of Setia Budhi. The figures of Partai Nasional Indonesia (PNI), with their Lembaga Kebudayaan Nasional/National Institute of Culture (LKN), establihed a group under the name of Suluh Budaya. While Partai Komunis Indonesia/Indonesian Communist Party 
(PKI), with its Lembaga Kebudayaan Rakyat/Institute of People Culture (LEKRA), estblished a play group under the name of Dharma Bhakti. These gorup only lasted until 1965 when the September 30 Movement (G-30-S/PKI) erupted these groups was disbanded because of the raging mass of anti-PKI. Since that time the function of the play, as well other art, was no longer accompanied by the interests of political parties (Haryani, 2013:41).

Later in the 1970s the Cirebon performing art was very popular. It is not surprising that in Cirebon that time many theatrical groups were established in villages and sub-districts. The play is still alive in Cirebon and surrounding communities. The artistic life is inseparable from the support of its supporters, which still requires the performing arts as an accompanist in initiation ceremonies, cathartic and sympathetic magic (marriage, circumcision, kaul, etc).

The musical instruments used in the Cirebon performing art is gamelan pelog with waditranya that include bonang, kemyang, saron, titil, penerus, large and small gongs, kendang, ketipung, and dogdog, tutukan, kenong (jenglong), kecrek, flute, and gambang. In a recent development, the modern musical elements are added, such as keyboards and electric guitars. Other equipments to support the Cirebon theatricals include properties, the display, and decoration.

In the current Cirebon theatrical performaning art, many featured stories are taken from the Babad Cirebon, such as the acts of Nyi Mas Gandasari, Pangeran Walangsungsang, Ki Gede Trusmi, Tandange Ki Bagus Rangin, Pusaka Golok Cabang, and others (Marianti, 2007:47). Nevertheless, sometimes it features fairy tales or legends of Java community in general, particularly in the performances that take place during the day. But at night, the stories performed are mostly taken from Cirebon Chronicle and finish early in the morning. Because of its egalitarian, it also packs with Cirebonan dangdut music or sometimes tayuban, as an interlude in the play performances. The Cirebon theatrical performinga art during the night usually starts at 20:00 and finishes at 03.30 in the morning. It structure is as follows: the opening music (tatalu); scene gimmick (surpraise with stage tricks, such as fireworks); opening dance; theatrical paly performances; closing, with music and the theater leader epilogue.

\section{The Theaterical Performing Art in the Globalization Exposure}

The lesser chance to perform degrades the quality of the local arts, therefore the actors felt abandoned by their supporters. Moreover, the local youth has no interest to pursue the traditional arts, because it is considered to have no prospects. Many former Cirebon performers's life are not good, some of them even do odd jobs. They easily "plead" that the decline of the Cirebonan theatrical performaning art is solely because of the strong exposure to modernization and globalization. They hardly examined the internal factors behind it. As an example, the aspect of "acting" or "theater world" was never analyzed as a flaw or weakness that hit the player in the act.

The world of actors or theater in Indonesia, Tommy F. Awuy in his writing titled Teater Indonesia dalam Ambiguitas dan Ironi, stated that the Indonesian theater is a theater that is full of ambiguity (Awuy, 1999:333). This is caused by many 
things, one of them is because Indonesia theater is still amateur theater, both in terms of directing, acting, and artistic arrangement. Each of these three aspects has no exact particular function and duties. Furthermore, Awuy explain that this ambigiuty also due to the fanatics who say that the art of theater, drama, plays as if it depends on the expression of reality, not a performance with a high ilusivity. In fact theater should be evasive, refusing, and even transcend reality. But on the other hand the art itself faces the changes in society and socio-cultural environment as the result of globalization laden with technology progress.

Giddens (1990:64), a professor of sociology at the University of Cambridge, said that currently the process of globalization is increasingly perceived as a part of our lives, where the "intensification of global social interaction is increasingly happening". The indicator is the establishment of the information superhighway; the highway of information witha very large capacity that enables traffic information super in high speed, political boundaries between nations of the world is diappearing (Ohmae, 2002:171173; 1991:183-186). Boyer and Drache (1996:64) in the States Against Market: Limits of Globalization explain that:

Globalization refers to the multiplicity of linkages and interactions between the states and societies which make up the present world system. It describe the process by which events, decisions, and activities in one part of the world come to have significant consequences for individuals and communities in quite different part of the globe. Globalization has two distinct phenomena: scope (or stretching) and intensity (or deepening). On the one hand, it defines a set of processes which embrace most of the globe or which operete world wide; the concept therefore has a spatial connotation. One the other hand, it also implies an intensication in the levels of interaction, interconnectedness or interdependence between the states and societies which constitute the world community.

Thus the essence of globalization as the subjective reality indicates a process in human consciousness that look and feel themselves as participants of increasingly unified global community. While the objective reality of globalization is a process of space and time narrowing, "shrinking" world that thrive in conditions of paradoxes. The paradox between the universalization versus pluralization, between integration versus fragmentation, between centralization versus autonomy, between competition versus cooperation, and so on (Naisbitt , 1994: 1-51).

Globalization receives popular concern both in the academic circle or common society. Most academic attention to the problem is motivated by public anxiety regarding globalization (Ritzer and Goodman, 2004:587). The influence of globalization are increasingly powerful, it needs special attention that are complex and unique. The uniqueness of globalization is not simply linked to that process is "going on" but also "how is our preparation to face globalization". Because we realize that the insistence of globalization is not likely to be encountered confrontationally, but it should not damage the the lives aspects, rights, and obligations of every nation. 
Kennedy (1995:290-292) has warned us in the description which is worrying for us, that there will be the group of countries that emerge as the winner and the other disadvantaged group as the loser, when the fundamental and revolutionary changing process happens. The existence of the winner and losers group is due to the lack of unanimity of perception and response of each country and nation toward the revolusiener globalization. There are a few countries that were able to quickly adjust to changes (fast adjusters) that are also have such a bold reforms, such as in several countries in East Asia. While others appear as a slow adjuster because they are not ready to face such changes. Obviously we do not want to be the loser group. But the issue is not the matter of want it or loses it, but ready or not. This is where a global perspective in the history of education in relation to the pressing of globalization is required.

Kennedy's simplified description of globalization, it appeared to emphasize in two things. First, the fact that the whole life of the global community, covering the whole nation and all aspects of life worldwide. Second, the effort to develop and strengthen the awareness about the reality of the global society, in the first sense it refers to the phenomenon of globalization, while in the second sense refers to the demand of the development in a global perspective through global education, so that people have the knowledge, attitudes, skills, and readiness to participate. They are expected to put themselves and interpret it in contributing to the present and future (Diaz, 1999:37-38). It is impossible and will only create new problems if we are to react in confrontational ways especially without any real preparations through human resource development..
Mickletwait and Wooldridge (2000:29) in the Future Perfect: The Challenge and Hidden Promise of Globalization explain that there are three engines gloaliztion to look at globalization from a different aspect. They review the motors that drive the globalization which result in a fast process of globalization through the boundaries between nations/states. Furthermore, they mentioned that globalization is driven by three determining engines.

... technology, the capital market, and management...Each of these forces is powerful enough in its own right, but what has given them their apparent invincibility in recent years is the fact that they all fit together so neatly. Freeflowing capital makes it easier for companies in even the most out-of-the-way places tu buy new technology. New technology makes it easier to move capital to similary obscure places. And managemen by which we mean the spread of common management methods, the growth of the management industry of consultants and business schools, and the development of new cadre of profesional multinasional managers alerts companies to the clever ways in which they can use capital and technology.

We realize the powerful resonance that hit in the globalization process, especially for developing countries, thus wereallyneed to respond it carefully and wisely, which requires real preparation steps through education and skills that strengthen the national identity. Only by strengthening the education and development of a strong national culture and implement the principle of interdependence in a 
global society, the resilience of a culture can be maintained and improved to live harmonioualy in uniformity and diversity.

\section{Research Methode}

\section{Approaching Method and Data Gathering Technique}

This study used a qualitative approach, the study emphasizes on the descriptions and interpretations without using statistics and mathematics. The method is a combination of ethnography and historical methods. Encyclopedia of Indonesia mentions ethnography as a branch of anthropology, the depiction and analysis of a community or ethnic group the culture. Ethnography usually consists of a detailed description of aspects of how to behave and ways of thinking that have been studied in people that are the standard, such as text, photos, images, or movies containing the report or description. Ethnography study the cultural elements of a society such as, language, livelihood, technology systems, social organization, knowledge systems art, and religion.

One of the qualitative research approaches, ethnography is used to examine human behavior related to the development of a particular culture. Brief explanation of some methods such as ethnography, ethnography is an early version of a society such as cultural elements, language, livelihood, technology systems, social organization, art, knowledge systems, and religion (Spradley, 1997:4). New ethnographic analysis in this study is not based solely on the interpretation of the researcher. While modern Ethnography is a major concern to the researchers was the life of the present, which is about the way of life of the community (Spradley, 1997:5). Ethnography usually contains/tells the tribe or a society, which usually told about the culture of the tribe or community. When researching public ethnographers typically a holistic approach and describe it in depth to memproleh native 's point of view.

Data collection techniques used were in-depth interviews and obeservation participation where this data collection method is in accordance with the original purpose ie mendeskripsiakan in depth. While the documentary studies are used to uncover the songs of the classical or traditional Cirebonan theatrical performance art and the dynamics when it is staged (Cresswell, 1994: 8-9).

The reason of using the ethnographic methods as a reference of this study is that it is considered to have advantages, such as: uncovering ethnographic journey from the early to the new form of ethnography. In addition, also provides practical steps to conduct ethnographic research of the new ethnography, which is then used to interpret the world around it, as well as to arrange the behavioral strategy in facing it. While the disadvantages of ethnography are that this method only observes the traditional or isolated communities and makes this ethnography only as a fundamental tool.

The historical aspect of this research will use the historical method (Sjamsuddin, 1996:63) - a method of research that reveals how to understand something through history. The reason researchers use historical methods is because the issues raised are of the Cirebon theatrical performing art history that occurred in the past, the Cirebonan theatrical performing art origins and the dynamics until now. 
FurthermoreSjamsuddin (1996:69) reveals several steps that must be carried out by history researchers in doing tehir reseach, including:

1. Choosing the appropriate title or topic.

2. Investigate all evidences that are relevant to the topic.

3. Make a note of foundings when the study is ongoing.

4. Physically know all evidences collected (source criticism).

5. Develop research results into a correct pattern or certain systematics.

6. Presenting and communicating it to the reader in a way that can attract attention, so it is understandable.

From the sixth steps, the steps of selecting a topic, collecting historical evidences, and making a note are included in the heuristics step of, while evaluating all historical evidences, including criticism and the last step of preparing and presenting research results are included $\mathrm{n}$ ithe stage of historiography (Sjamsuddin, 1996:65).

As for the data collection techniques, researchers used data collection techniques of (1) observation, (2) interviews (3) documentation. Observations are used to directly observe the Cirebonan performing art performances. Interviews were conducted to explore further information about the things related to reserach through a number of research questions. While the documentation technique is by obtaining information about the Cirebonan theatrical performing art by reviewing various sources that have been obtained from various documents, such as artifact, mentifact, and socifact. These data collection techniques are expected to complete the necessary data. Thus, this study will contain data in the form of quotations, whether from literature studies, interviews, fieldnotes, photograph, recording-tape video, personal documents, notes/memos, official documents and others. Observation notes are the date of recording, the recording location (the state of the society), original recording or not, the person doing the recording. While the notes about the informan includes: name, age, gender, occupation, education, ethnicity, position in society, actively wacth the at traditional Cirebonan theatrical performing art or not.

\section{Research Time, Place, and Subject}

This study was conducted in JuneOctober, 2013, which location is on the north coast of Java, particularly the region of Cirebon and Indramayu. The object this study is the Cirebonan teatherical performing art artists (directors, actors, musician), and the audience.

The subjects of this study are the following details:

1. Group: Dwi Warna, Manager: Syamsul Bahri (60), Director: Husen Kemleng (70) Actors: (1) Wulan Purnama, Alamat Losarang Indramayu;

2. Group: Dharma Saputra, Leader: Serma H. Suana, NS; Actors: Nargi (45), Topeng dancer, Said Ramdhani, Wanto Aspal; Address: Desa Plumbon Kab Indramayu;

3. Group: Sandiwara Jaya Utama, Leader: Guru Umin; Address: Desa Sambeng, Kec. Gunungjati, Kab. Cirebon;

4. Group: Lingga Buana; Leader: Asep Kurniawan S.Kes., Address: Losarang Kab Indramayu; Actors: Sellyyudha Aprilyanti Kadiman. 
5. Group: Chandra Sari; Leader Ki Dalang Abdul Bagir Muslim; Address: Kedung Legok, Lohbener, Kabupaten Indramayu.

6. Group:Jaya Baya,Leader:H.Salamahadi; Actors: Aan Tanggung, Ratna Mila, Tau Pong Kres; Address: Cirebon.

7. Group: Aneka Tunggal(Cirebon) Leader: Bpk H. Didi / Mamah Hj. Iti; Actors: Joni Rengge; Address: Desa Nanggela Greged Kabupaten Cirebon.

8. Group: Chandra Sari, Leader: H. Eddy Nuradi S.E., (55), Address: Desa Kedunglegok Kec.Loh Bener Indramayu.

9. Group: Aneka Tunggal, Leader: H.Ono Kustono, Actors: Joni R, Dewi Ayu, Devi Susilawati, Aar, Herman; Address: Pawidean Jatibarang, Indramayu.

\section{Data Analysis Technique}

The analysis of the data is following the pattern of Miles and Huberman (1992:1618), which consists of three flow events that occur simultaneously, that include: data reduction, data presenting, and conclusion. Data reduction is a process of selecting, which focus on simplification, abstraction, and rough transformation that emerged from the written notes in the field. Then proceed with the data presentation in the form of descriptions based on the aspects studied and arranged in a row on the analysis of the Cirebonan theatrical performing arts. While the conclusion/verification, in this case the conclusion is achieved in stages, the first is a tentative conclusion. However, with the increase of data, it is necessary to verify the data returned by studying the existing data (which is reduced or presented). Moreover, the related parties opinion were also asked, with respect to this research (Miles and Huberman, 1992:17), which were the Cirebonan theatrical actors, pawang, and gamelan musician, as well as the audiences.

\section{Research Result and Discussion}

Theresearch begins bybymaking simple research instruments, the interview, that include the following questions: (1) what is the origin of the Cirebonan theatrical performances art theatrical performing art in the coastal areas of West Java border? (2) For what purposes the Cirebonan theatrical performing art is perform in the coastal areas or border West Java? (3) What are the steps of the performance so it can be enjoyed as ordinary folk art performances? (4) What is the philosophy value that can be contoribute for history education? (5) What is the efforts to increase the hostorical awareness in the local community to enjoy the performing arts that increasingly marginalized by the globalization exposure?

The results of this study in are as follows:

\section{The Origin of Cirebonan/Masres Theaterical Performing Arts in West Java}

The origin of Cirebonan/Masres theatrical performing arts, when asked, "since when the Cirebonan theatrical art exist in the border area of the north coast of West Java and Central Java?" Samson Bahri (DW), Serma H. Suana, NS, (DS), Asep Kurniawan (LB) stated: "Ya konon kata wong tua gemien umumme ya jaman Jepang kurang lebih tahun 19431944". Likewise, when the question was asked to Salamahadi (JB), and Pak Didi 
(ATC), They answered "ya kurang lebih tahun 1944, soal le perek karo Indonesia Merdeka ingatanku kaya kue".

It can be concluded that the Cirebonan/ Masres theatrical performing arts is started in 19403/1944s, and it appeared when the Cirebon was occupied by the Japanese colonialists. Based on the information gathered by the Cirebonan theatrical figures that during the Japanese occupation of Indonesia, there was Reog Cirebonan which popular as as Reog Sepat. The show was divided into two parts. First, bodoran/ jokes, and the second was a drama that took the story of the local people's habits. At the same time, in Jamblang Klangenan there were also an art that commonly known by the name of Cahya Widodo tonil. This art did narayuda (perform) every day, in months. Both types of art are then inspired a young man from the Langgen, Wangunarja village, named Mursid to establish a new art in Cirebon. He gathers local young people to jointly establish a type of art which is a blend of Reog Sapet and Chaya Widodo tonil. The art is a form of drama with musical of Cirebonan supported style by waditra in the Prawa rythim. This art is called Jeblosan which means they are performing according to toneel without curtain (In Cirebon language, jeblas-jeblos). It was also called Bungkrek (Cirebon language which means the single people (youth) that are often angkrak - engkrek, or dancing ) by some people.

\section{The Purpose of Cirebonan Theatrical Performing Arts.}

When asked the question of "what is the purpose of the Cirebonan/Masres it theatricalperformingartperformance?",the artists,(EdiNuradi(CS), Ono Kustono(AT), and Dedi Supriya, the Head Disbudparpora of Cirebon, answered that it is generally for entertainment. But, the answer of Mr. Rasmadi, the leader of the Sandiwara Budi Suci Group is a little different, he stated: "In addition to entertainment the Masres theatrical performing art is also to recall the history and development of the region". "I've been asked by the local government of Cirebon through the Department of Culture, Tourism, Youth, and Sports (Disbudparpora), for the new year event of 2013, to play Babat Cirebon". According to Abdul Bagir But Muslim (CS) and Mamah Iti (AT) in fact most of the responders particularly asked the fighting stories of certain figures such as: Nyi Mas Gandasari, Pangeran Walangsungsang, Ki Gede Trusmi, Tandange Ki Bagus Rangin, and Pusaka Golok Cabang, and so on. However, it also have a little shift in function, according to Syamsul Bahri (DW), the government also utilize it as the media for preaching purposes (Islam), spreading information, such as the family planning, general election, young married prevention, and so on.

\section{The Steps of Performing the Cirebonan Tehaterical Performing Arts.}

After asking about the steps or performing the Cirebonan/Masres Theaterical Performing Art? It turns out that in general, (Samson Bahri (DW), Serma H.Sauna, HS (DS), and Guru Umin (JU) stated that the sequences of performing steps of the Cirebonan/Masres theatrical performing art are as follows : (1) the opening music (tatalu), (2) scene gimmick (surpraise with stage tricks, such as fireworks), (3) the opening dance, (4) the theatrical performances, (5) closing, with music and the theater leader's epilogue. 
First, the opening music (tatalu) is the opening music by instrumental tracks, which function is to attract potential audience as well as the marker that the performance has begun. Typically, this music is called karawitan or gendingan. The music player is commonly referred as panjak or pengrawit. The music starts from the beginning of the performances until it is finished. The purpose of the music play at the beginning of the show is to steal the attention of the potential audience, especially the surrounding residents.

While the instrument used in the Cirebon theatrical performing art is gamelan pelog with the waditra including bonang, kemyang, saron, titil, penerus, large and small gongs, kendang, ketipung and dogdog, tutukan, kenong (jenglong), kecrek, flute, and gambang. In a recent development, the modern musical elements are added, such as keyboards and electric guitars. Other equipment to support the performance are properties, the screen, and decoration.

Second, the gimmick scene. This is in the beginning of a story that serves as a audience attractor to keep watching the play. Usually this begins with fireworks, firecrackers to surprise the audience.

Third, the opening dance. This step is both rhythmic gestures that are performed in a certain time and place for the purposes of the association, expressing feelings, intentions, and thoughts. The sounds, which called the dance music, control the dancers' movement and strengthen the intention to be conveyed. Different dance movements of everyday movements such as running, walking, is the mainstay dance which is the characteristic of a particular play as an opener .
Fourth, the theatrical performances. This theatrical performance is the core performance that consists of battle between the evil (antagonist) and the good (the protagonist). Although eventually the war between these two powers will be won by the power of good (the protagonist), but it should be achieved through sacrifice and miserable fight or not easily. Some of the stories or plays that are often played in the Cirebonan theatricalperformancegenerally range from Babad Cirebon which include: the play of Nyi Mas Gandasari, Pangeran Walangsungsang, Ki Gede Trusmi, Tandange Ki Bagus Rangin, Pusaka Golok Cabang, and other.

Fifth, the closing scene. Usually the closing scenes is accompanied by music and epilogue of the thater leader while delivering the play summery in beautiful words, as well as the reflections of the audience. It will end with closing remarks of apologizing for any unpleasing scenes.

\section{The Phylosophical Values of the Cirebonan Theaterical Performing Art in the History Education}

The phylosopical value of the Cirebonan/Masres theatrical performance art is that this art is obviously a combination of cultural and spiritual, according to the Regent of Cirebon, Dedi Supardi. Further, Guntur Sigar Langit said:

Although it is relatively rare appears in public, but performance is still occurs. For example, Masres, the traditional theatrical that often performs stories of the Cirebon history, since Islam spread in the quiet hamlet which later named the Cirebon. This Masres is unique for several reasons. First, the 
intervention of the director who is not dominant: the players are free to improvise as long as not refracted from the core story. Second, the everyday professions of the players are diverse, such as rickshaw drivers, domestic workers, fishermen, and farmers. Third, the involvement of canvas painters for the display screen setting of the stage in accordance to the episode story. The masres studio that can be found on the north coast of Cirebon (Kapetakan districts, Cirebon regency) indicates that there is commitment to preserve the local art, eventhough it has to deal with a number of the contemporary reality.

This is the uniqueness of Cirebon culture, particularly the Masres Theatre Arts, with a reflection to the story/history of Cirebon in the minds of the people and then it can be poured into the form of performing arts, it is a blessing to be grateful. How oral stories that developed was recorded so strong in the Cirebon society, especially in the artists. This fact is the reason why a famous director Arfin C. Noer sais, "If you want to learn the theater come to Cirebon". He must mean the Masres.

Cirebon culture that reportedly absorbed from Java (Islamic Mataram Kingdom) and Sunda occupies a unique position. Two major culture on the island of Java met in Cirebon. Culture was even more complete absorption synthesise Islamic spirituality. This is the Cirebon culture share. And this share filled the local art space. From this come the folk artists. The artists that work without dependent to the director's instructions, while when not performing they do their daily profession.
If sometimes appears that the perceived value of mystical quietly burst on the art traditions of Cirebon, for example, the existence of dupa and kemenyan (incences), or flowers of seven colors - it was not a media to invite supernatural powers. But the smoke of incense and flowers it is a relic of Javanese culture derived from the teachings of Hinduism. The play is suspected Cirebonan example often mythical. This should be clarified because the provision of adequate training in a short time with the body of a woman bound and put in confinement can changing costume.

Talking about the culture of Cirebon is inseparable from the existence of the old proverb, better known by the name of wangsalan. Wangsalan is a method of teaching that parents do to their children. To explain cosmology and geography easily, parents use wangsalan: Nungsitu Nangsiton means gunung isie watu nagka isie beton, Tangkehteng Lanjidang means bintang akeh peteng bulan siji padang. To explain the occurrence of demoralization, the wangsalan is: wong lanang ilang prawirae wong wadon ilang wirange which means man lost his manlyhood woman lost her shame. To explain the progress of time because of the technology that continues to evolve, wangsalan is described as engko bakal akeh wong ngomong dewek kaya wong edan, that indicates more and more people will talking to themselves (over the phone) like crazy man .

\section{Effort to Enhance the People and Government's History Awareness in Preserving the Cirebonan Perfroming Art}

Some community leaders said that efforts have been done to raise historical 
awareness, especially to preserve the Cirebonan theatrical performaning art. The mayor of Cirebon, Ano Sutrisno, in his speech on June 27, 2013 when opening the topeng art exhibition at the soccer field of Derajat village, Kesambi Cirebon, said:

.... arts and culture should not be interpreted narrowly limited to artists and cultural. However, it is a multidimensional realm of values, ethics, norms, aesthetic, and social institutions. "Art culture that exist from generation to generation and dynamic suct as Topeng Dance, Tarling, and Play is part of the character and identity of the nation,"

The head of Department of Tourism Culture Youth and Sports (Disbudpora) of Cirebon, H. Asdullah, has the same opinion after watching the show of Masres theatrical groups of "Holy Budi", he argued "we will continue to preserve the theatrical/Masres as an integral part of our program to make Cirebon as the Tourism City. In fact, he promised to always promoting education programs to the actors as the real effort to preserve the precious cultural heritage. Elang Heri (41), the leader of Sanggar Seni Sekar Pandan on the opportunity to be the host of the monly art performance in the field at Jalan Sultan Kacirebonan Pulasaren, Pekalipan District, of Cirebon said the similar opinion: "The point is for young people to participate in preserving the culture of Cirebon "said Elang Heri .

For the art people of Cirebon, Sekar Pandan name is fairly familiar, because of Elang Heri teaching and also their often performancein various stage. Moreover, the name of the late Sudjana Ardja, the maestro of Slangit Mask Dance was also listed as an instructor in a studio that was established in that time. Likewise, when researchers try to ask another artist such as Mr. Didi (AT) and Eddy Nurady (CS), they argued: "That's why we are still actively playing in the theaterical art until now, precisely because we were concerned to preserve the theatrical art forthe youth. While the real effort to preserve the theatrical art /Masres is by performing the traditional art during local ceremonies. "Such as Mapag Sri or Nadran,” said Asdullah.

\section{Conclusion}

The Cirebonan theatrical performing arts or Masres, which is one of the traditional art of Cirebon (the northern coastal areas of Java, particularly Cirebon and Indramayu), is essentially reflected the quality of communication, situation, action (everything that comes to the stage) that raises concern, excitement, and strain on the viewers, which depicted the life through motion or action presented as one kind of Cirebon Cirebon' art, can be summed up as follows :

First, about the origins of birth Theatre Cirebonan / Masres . Most people mentioned that this art was born in the era of Japanese occupation around the year of 1943-1944, as an entertaiment as well as a tool to fight. There was Reog Cirebonan which popular as as Reog Sepat. The show was divided into two parts. First, bodoran/jokes, and the second was a drama that took the story of the local people's habits. At the same time, in Jamblang Klangenan there was also an art that commonly known by the name of Cahya Widodo tonil. This art did narayuda performence every day even performed regularly in saveral month. Both types of art are then inspired a young man from the Langgen, Wangunarja village, Mursid who establishes a new art in Cirebon. He gathers 
local young people to joint the arts blended from Reog Spet and Cahaya Widodo tonil. The art is a form of drama with musical Cirebonan and the style is supported by waditra in the Prawa rhythim. This art is called by some people Jeblosan which means they ussualy performs without toneel without curtain (In Cirebon language, jeblasjeblos). It was also called Bungkrek (Cirebon language which means the single people (youth) that are often angkrak - engkrek, or dance).

Second, the purpose of Cirebonan theaterical performing arts, according to the artists and figures in the society of Cirebon, is generally for entertainment and also to recall the history and development of the region and to immitate figures such as Nyi Mas Gandasari, Pangeran Walangsungsang, Ki GedeTrusmi,TandangeKi Bagus Rangin, and Pusaka Golok Cabang, and so on. However, it also have a little shift in function, according to Syamsul Bahri (DW), the government also utilize it as the media for preaching purposes (Islam), spreading information, such as the family planning, general election, young married prevention, and so on .

Third, the sequences of performing steps of the Cirebonan/Masres theatrical performing art are as follows : (1) the opening music (tatalu), (2) gimmick scene (surpraise with stage tricks, such as fireworks), (3) the opening dance, (4) the theatrical performances, and (5) closing, with music and the theater leader's epilogue. The opening music (tatalu) is the opening music which function to attract potential audience as well as the marker that the performance has begun. Typically, this music is called karawitan or gendingan. The music player is commonly referred as panjak or pengrawit. The music starts from the beginning of the performances until it is finished. The purpose of the music play at the beginning of the show is to attract the attention of the potential audience, especially the surrounding residents. While the instrument used in the Cirebon theatrical performing art is gamelan pelog with the waditra including bonang, kemyang, saron, titil, penerus, large and small gongs, kendang, ketipung and dogdog, tutukan, kenong (jenglong), kecrek, flute, and gambang. In a recent development, the modern musical elements are added, such as keyboards and electric guitars. Other equipment to support the performance are properties, the screen, and decoration.

After that, the gimmick scene. This is in the beginning of a story that serves as an audience attractor to keep watching to the play. Usually this begins with fireworks or firecrackers to surprise the audience. Next is the opening dance. This step is both rhythmic gestures that are performed in a certain time and place for the purposes of the association, expressing feelings, intentions, and thoughts. The sounds which is called the dance music controls the dancers' movement and strengthen the intention to be conveyed. Different dance routines of everyday movements such as running and walking are the main dance routines, which is the characteristic of a particular play as an opener. After that, it is the theatrical performances. This theatrical performance is the core performance that consists of battle between the evil (antagonist) and the good (the protagonist). Although eventually the war between these two powers will be won by the power of good (the protagonist), but it should be achieved through sacrifice and miserable fight or not easily. Some of the stories or plays that are often played in the Cirebonan theatrical performance generally 
range from Babad Cirebon which includes: the play of Nyi Mas Gandasari, Pangeran Walangsungsang, Ki Gede Trusmi, Tandange Ki Bagus Rangin, Pusaka Golok Cabang, and others. The last step is the closing scene. Usually the closing scenes are accompanied by music and epilogue of the thater leader while delivering the play summery in beautiful words, as well as the reflections of the audience. It will end with closing remarks of apologizing for any unpleasing scenes.

Fourth, the phylosopical values of the Cirebonan/Masres theatrical performance art is that this art is obviously a combination of cultural and spiritual, which characteristic are (1) director interference that is not dominant; the players are free to improvise as along as it still on the core story. (2) the everyday profession of the players as diverse, such as rickshaw drivers, domestic workers, fishermen, and farmers. (3) the involvement of canvas painters for the display screen setting of the stage in accordance to the episode story. The masres studio that can be found on the north coast of Cirebon indicates that there is commitment to preserve thelocal art, eventhough it has to deal with a number of the contemporary reality. Moreover, with a reflection to the story/history of Cirebon in the minds of the people and then it can be poured into the form of performing arts, it is a blessing to be grateful. How oral stories that developed was recorded so strong in the Cirebon society, especially in the artists. This fact is the reason why a famous director Arfin C. Noer sais, "If you want to learn the theater come to Cirebon". He must mean the Masres.

Fifth, efforts have been done to raise historical awareness, especially to preserve the Cirebonan theatrical performaning art. Efforts were made to increase the awareness to preserve the history of theatrical performance art, some community leaders suggested that "we've been trying hard to preserve the theatrical performancing art, both expressed by local officials (formal) and theatrical performers themselves, as well as the cultural observer. While the real effort to preserve the theatrical art /Masres is by performing the traditional art during local ceremonies. "Such as Mapag Sri or Nadran,"

It may be true that this expression have offendedthementalattitudeofCirebonpeople in general, that: "wong wong prawirae lanang ilang ilang wadon wirange" which means that men lose his heroism, while women lost her sahem. What it means is almost all Cirebon people, realize it or not, are now in the era of globalization, and it appears to lose all of its Cirebon cultre identity. Society on the one hand has been less concerned with Cirebonan theatrical performing art, while some Cirebonan theatre arts group went bankrupt because of there no invitation to perform, an lost tothe single organ that is a more vulgar. On the other hand, ironically, from formal education people ( the Head of the Department of Education and Culture, the principal, and teachers in the school) does not seem to have real effort to seriously preserve the Cirebonan theatrical art. This proved by the lack of efforts to develop a Local Content Curriculum by developing local arts and culture to preserve and improve it.

\section{REFERENCES}

Andersen, R. dan Cusher, K. (1994). Multiculturaland intercultural studies, dalam Teaching Studies of Society and Environment (ed. Marsh,C.). Sydney: Prentice-Hall

Awuy, T.F (1999) ":Teater Indonesia dalam Ambiguitas dan Ironi” dalam Teater Indonesia, Jakarta: Dewan Kesenian Jakarta, halaman 330-335, 
Borries, Bodo von (2000). Methods and Aims of Teaching History in Europe: A Report on Youth and History, dalam Knowing Teaching \& Learning History: National and International Perspectives (Eds. Stearns, P.N., Seixas,P., Wineburg,S.). New York: New York University Press.

Boyer, Robert \& Drace, Daniel (1993) States Againts Market: The Limits of Globalization, London dan New York: Routledge.

Creswell, J.W. (1994). Research Design Qualitative \& Quantitative Approach. London: Publications,

Diaz, C.E. Massialas, B.G. \& Xanthopoulos, J.A.(1999) Global Perspective for Educator. Boston, London: Alyn \& Bacon.

Giddens, A. (1990). The Consequences Modernity. Stanford, Calif.: Stanford University Presss.

Giddens, A. (2000). Runway World: How Globalization Is Reshaping Our Live. New York, Routledge

Haryani, H. (2013). Tari Serimpi pada PertunjukanSeniSandiwaraKelompok Darma Saputra Kecamatan Plumbon Kabupaten Indramayu, Skripsi (Tidak Dipublikasikan), Fakultas Pendidikan Bahasa dan Sastra, Pendidikan Seni Tari, Fakultas Pendidikan Bahasa dan Sastra, Universitas Pendidikan Indonesia, Bandung, 2013.

Lull, J. (1998). Media, Komunikasi, Kebudayaan. Terjemahan Parakitri T.Simbolon, Jakarta: Yayasan Obor Indonesia.

Kellner, Douglass (2002). "Theorizing Globalization" dalam Sociology Theory 20: hlm. 285-305.
Kennedy, P. (1995). Menyiapkan Diri MenghadapiAbadke21.Diterjemahkan Oleh Yayasan Obor Indonesia. Jakarta: Yayasan Obor Indonesia

Levstik,L.S. (2000). Articulating the Silences: Teachers' and Adolescents' Conceptions of Historical Significance, dalamKnowingTeachingandLearning History: National and International Perspectives, Knowing Teaching and Learning History: National and International Perspectives. ed. Stearns, P.N., P. Seixas, dan S. Wineburg.

Marianty,W.A,S.(2007).LayarSandiwara Masres Kelompok Dharma Samudera Cirebon: Analisis Layar dalam Cerita Jaka Pendil. Tesis Untuk Memperoleh Salah satu Syarat Gelar Magister (Tidak Dipublikasikan), Institut Teknologi Bandung.

Marsh, C. (Ed.) (1994). Teaching Studies of Society and Environment. Sydney: Prentice-Hall

Miles, M., dan Huberman, M., (1992) Analisis Data Kualitatif: Buku Sumber tentang Metode-metode Baru. Penerjemah: Tjetjep Rohendi Rohidi, Jakarta: UI Press.

Miclethwait, J. \& Wooldridge, A. (2000) Future Perfect: The Challenge and Hidden Promise of Globalization. New York: Random House, Inc.

Mundardjito (1986). "Hakikat Local Genius dan Hakikat Data Arkeologi”. Dalam Ayatrohaedi. Kepribadian Budaya Bangsa (Local Genius). Jakarta: Pustaka Jaya, halaman 39-45.

Mustafa, H. (2002). Adat Istiadat Sunda. Penerjemah Maryati Sastrawijaya, Bandung: Alumni. 
Naisbitt, J. (1994). Global Paradox. Alih Bahasa : Budijanto, Jakarta: Binarupa Aksara.

Ohmae. K. (1993). Dunia Tanpa Batas. Alih Bahasa Budiyanto. Jakarta: Binarupa Aksara.

Ohmae. K. (2002). Hancurnya NegaraBangsa : Bangkitnya Negara Kawasan dan Geliat Ekonomi Regional di Dunia tak Berbatas. Penerjemah Ruslani. Yogyakarta: Qalam.

Ritzer. dan Goodman. (2004). Teori Sosiologi Modern. Edisi Keenam. Terjemahan Alimandan. Jakarta: Prenada Media.

Sedyawati. E. (1986). "Local Genius dalam kesenian Indonesia". Dalam Ayatrohaedi. Kepribadian Budaya Bangsa (Local Genius). Jakarta: Pustaka Jaya. halaman 186-192.

Sitorus. Eka. D. (2002). The Art of Acting (seni Peran untuk Teater. Film. dan TV). Jakarta: PT Gramedia.

Sjamsuddin. H. (1996). Metodologi Sejarah. Jakarta: Depdikbud. Proyek Pendidikan Tenaga Akademik.

Spradley. J. (1997) Metode Etnografi. Penerjemah Misbah Zulfa Elizabeth. Yogyakarta: Tiara Wacana.

Soebadio. H. (1986). Kepribadian Budaya Bangsa. Dalam Ayatrohaedi. Kepribadian Budaya Bangsa (Local Genius). Jakarta: Pustaka Jaya. halaman 18-25.

Stanislavsky, K. (1989). An Actor Prepares.

New York: Routledge/Theatre Arts Books.

Sumardjo. J. (2004). Perkembangan Teater Modern dan Sastra Drama Indonesia. Bandung: STSI Press.
Supardan. D. (2000). Kreativitas Guru Sejarah dalam Pembelajaran Sejarah (Studi Deskriptif-Analitis terhadap Guru dan Implikasinya untuk Program Pengembangan Kreativitas Guru Sejarah SMU di Kota Bandung). Tesis Untuk Memperoleh Gelar Magister Pendidikan. Pascasarjana UPI Bandung.

Supardan. D. (2002) "Keberhasilan Kebijakan Multikulturalisme Kanada dan Tantangannya: Studi Hak Azasi Manusia dalam Perspektif Global". Jurnal Pendidikan Ilmu Sosial (JPIS). Bandung: FPIPS UPI.

Supardan. D. (2003) "Turbulensi dan Bahaya Kekerasan dalam Pendidikan”. Dalam Helius Sjamsuddin \& Andi Suwirta. Historia Magistra Vitae: Menyambut 70 Tahun Prof.Dr.Hj. Rochiati Wriaatmadja.M.A.Bandung: HistoriaUtamaPress.Suparlan.Parsudi. (2002) "Menuju Masyarakat Indonesia yang Multikutural”. Jurnal Antropogi Indonesia. tahun XXVI. No.69. UI dan Yayasan Obor Indonesia.

Supardan, D. (2011). Seni Pertunjukan Sandiwara Cirebonan: Memudarnya Kesadaran Sejarah di Peseisir Perbatasan Jawa Barat-Jawa Tengah. Laporan Penelitian. Tidak dipublikasikan. Jurs Pendidikan Sejarah FPIPS UPI Bandung.

Sutrisno, M. dan Verhak. C. (1993). Estetika Filsafat Keindahan. Yogyakarta: Kanisius.

Tambunan, M. (2004). Sejarah Musik dalam Ilustrasi. Jakarta: Progress.

Toffler, A. (1992). Pergeseran Kekuasaan: Pengetahuan. Kekayaan. dan Kekerasan Di Penghujung Abad ke 
DADANG SUPARDAN, DIDIN SARIPUDIN, AYI BUDISANTOSO, AND SYARIF MUIS

The Cirebonan Theatrical Performing Art in the Middle of Globalization Exposure

21 (Bagian Kedua). Alih Bahasa: Hermawan Sulistyo dkk. Jakarta: PT Pantja Simapti.

Umar, K.(1981).Seni.Tradisi.Masyarakat. Jakarta: Sinar Harapan.

Wallerstein. I. (1996) "Ekonomi Dunia Kapitalis” dalam Roy C. Macridis \& Bernard E. Brown. Perbandingan
Politik: Catatan dan Bacaan. Alih Bahasa Henry Sitanggang, Jakarta: Erlangga.

Wales, H.G. Quartrich (1948) "The Making of Greater India: A Study in SouthEast Asia Culture Change”, Journal of Royal Asiatic Society, halaman 2-32. 